N. Limanska ${ }^{1}$, T. Ivanytsia ${ }^{1}$, Y. Choiset ${ }^{2}$, N. Korotaeva ${ }^{1}$, Zh. Sergeeva ${ }^{1}$, J.-M. Chobert ${ }^{2}$, V. Ivanytsia ${ }^{1}$, T. Haertlé ${ }^{2}$

${ }^{1}$ Odessa National I.I. Mechnikov University, 2, Dvoryanska str., Odessa, 65082, Ukraine

${ }^{2}$ UR 1268 Biopolymeres, Interactions, Assemblages, Institut National de la Recherche Agronomique (INRA), BP 71627, rue de la Géraudiére, 44316 Nantes Cedex 3, France

\title{
EFFECT OF ENTEROCOCCUS DURANS BACTERIOCIN ON BACTERIAL WILT AGENT
}

\begin{abstract}
Effect of a bacteriocin produced by Enterococcus durans A5-11 on growth of Ralstonia solanacearum strains and their ability to cause wilt in tomatoes was investigated. Among tested phytopathogenic strains, 33\% were sensitive and inhibited as it was shown after spotting bacteriocin on Ralstonia lawns. Minimal inhibitory concentrations and sizes of lysis or inhibition zones varied depending on the strain used for study. The same differences were evidenced for the effect of the bacteriocin on Ralstonia in a liquid medium and when inoculating Lycopersicon esculentum Mill test plants. Treatment of plant roots with the bacteriocin of E. durans A5-11 simultaneously with inoculation with bacteria of a highly susceptible strain $R$. solanacearum 6189 resulted in diminished number of wilted tomatoes.
\end{abstract}

Key words: Ralstonia solanacearum, Enterococcus durans, bacteriocin, wilt of tomatoes.

\section{Introduction}

Ralstonia solanacearum [32] causes bacterial wilt in a wide range of plant hosts. Depending on its strain, the pathogen infects economically important species from genera Solanaceae (potato, tomato, pepper, tobacco, egg plants), Musaceae (banana), Malvaceae (cotton), Zingiberaceae (ginger, curcuma), Euphorbiaceae (rubber), etc. [10;11;14;24].

The disease is mostly dangerous in the tropical and subtropical climatic zones with increased humidity, but the infections caused by strains adapted to cold temperatures (race 3 ) can occur also in temperate climate $[20 ; 30]$.

As biological control agents used against bacterial wilt, avirulent Ralstonia [31], actinomycetes like Streptomyces coralus [2] and bacteria of Pseudomonas and Bacillus genera are the most known [5; 7; 9; 28]. Antagonistic bacteria have been isolated from soil like Bacillus spp. inhibiting growth of $R$. solanacearum from Curcuma alismatifolia Gagnep. [28], or from plants like $P$. fluorescens found in healthy roots of Solanum melongena L. [4]. Among other microorganisms, satisfactory results were

(C) N. Limanska, T. Ivanytsia, Y. Choiset, N. Korotaeva, Zh. Sergeeva, J.-M. Chobert, V. Ivanytsia, T. Haertlé, 2012 
obtained applying Enterobacter cloaceae, Pichia guillermondii, Candida ethanolitica [22; 23], and Stenotrophomonas maltophilia [19].

Lactic acid bacteria (LAB) dwell on plant surfaces and can compete therefore with the phytopathogens for nutrients and attachment sites. For instance, Enterococcus durans bacteriocin-producing strain was initially isolated from the carrot peel [13].

A biopreparation EM4 containing $90 \%$ of other LAB - lactobacilli and the remaining percentage of photosynthetic bacteria, fungi and yeasts - had a positive effect on humus formation in soil resulting in increased growth of test plants [12]. EM4 bacterial mixture has also shown a protection effect against some phytopathogens [3], including Ralstonia solanacearum [18]. These results demonstrate the potential of LAB use in agriculture for plants protection against bacterial wilt.

The objective of this work was to estimate the possibility of bacterial wilt control by metabolites of LAB Enterococcus durans.

\section{Materials and methods}

Ralstonia solanacearum strains used in this study were kindly provided by Dr. L.D. Varbanets: R. solanacearum ATCC 11696, ICMP 7859 (bv 1), 7944, 6189, 8202, 749, 4157, 8089, 7954, 758, 7986. Strains VC4, ML, TS3, HL, TX1, KL2, HD2 were kind gifts from the Institute of Agricultural Genetics (Hanoi, Viet Nam). All studied strains were stored in LB-broth with $20 \%$ glycerol at $-20{ }^{\circ} \mathrm{C}$.

Enterococcus durans A5-11 strain was isolated from Mongol yogurt in BIA-FIP laboratory of INRA, France [1;8].

Bacteriocin from Enterococcus durans A5-11 strain was purified by cation-exchange chromatography, reversed phase chromatography and HPLC-chromatography with CHT-column according to Batdorj et al. [1]. Bacteriocin solutions of different concentrations $(0.10-0.03 \mathrm{mg} / \mathrm{ml})$ were stored at $+4{ }^{\circ} \mathrm{C}$ and $-20{ }^{\circ} \mathrm{C}$, and were adjusted to $\mathrm{pH} 6.8-7.0$ before use for test of antagonistic activity.

Initial screening for susceptible strains was performed using doubleagar layer method [27]. Pre-poured 1.5\% LB agar was overlaid with a soft agar $(0.6 \%$ LB) containing $10 \%$ bacterial culture in an exponential phase of growth. Enterococcal bacteriocin was spotted on the upper agar surfaces ( $5 \mu$ l of each repeat), and Petri dishes were incubated overnight at $28-30{ }^{\circ} \mathrm{C}$. The results of tests were obtained by observation of clear zones of bacteriocin activities. Serial dilutions were made to determine the minimal inhibitory concentrations (MIC) of bacteriocin.

To prove the antagonistic action of proteinaceous enterococcal bacteriocin and to exclude the effect of other compounds in investigated solutions, the samples of bacteriocin were treated with proteinase $\mathrm{K}$ (Amersham) according to manufacturer's instructions. 
Н.В. Ліманська, Т.В. І̇ваниця, І. Шуазе, Н.В. Коротаєва, Ж.Ю. Сергєєва, Ж.-М. Шобер, ....

Study of antagonistic effect was also carried out in a liquid medium. Mixtures containing cultures of phytopathogens in exponential phase of growth $(50 \mu \mathrm{l})$, LB-broth $(1 \mathrm{ml})$, and bacteriocin $(500 \mu \mathrm{l})$ initial concentrations of $0.2 \mathrm{mg} / \mathrm{ml}$ and $0.1 \mathrm{mg} / \mathrm{ml}$ were prepared to investigate the dynamics of microbial growth measured by counting viable cells inoculated on Petri dishes with LB-agar and incubated overnight at $28^{\circ} \mathrm{C}$.

Root dipping method was performed immersing roots of Lycopersicon esculentum Mill. cv Odessa pearl plants at a stage of three leaves into different mixtures of bacterial suspensions and antagonistic substances [25] prepared as mentioned below. Tips of roots were preliminarily damaged to insure the penetration of Ralstonia. For this part of experimental work, two strains of tested $R$. solanacearum $(R$. solanacearum 6189 and $R$. solanacearum 7859) showing different results in sensitivity were used.

Positive control plant roots were dipped for $1 \mathrm{~h}$ into suspensions of $50 \%$ of overnight pathogen cultures (concentrations 2-4 x $10^{9} \mathrm{CFU} / \mathrm{ml}$ ) and $50 \%$ of sterilized distilled water (SDW). Negative controls were soaked in SDW for the same time. 50:50\% suspensions of overnight $R$. solanacearum cultures and enterococcal bacteriocin (concentration $0.03 \mathrm{mg} / \mathrm{ml}$ ) were prepared and immediately used for $1 \mathrm{~h}$ treatments of plant roots. In such treatment, plants were exposed to pathogens and to antagonistic substance at the same time [18], but without preliminary interaction of Ralstonia and antagonistic substances. The control and inoculated tomatoes were planted into commercially available non-sterile nursery soil with abundance of peat ( $\mathrm{pH} 5.8-6.0)$ and placed in a greenhouse for 2 weeks with $70-75 \%$ of humidity and $26-30{ }^{\circ} \mathrm{C}$ air temperature. Number of treated plants was 20 of each variant in each of three independent experiments. The results of inoculation were evaluated in 14 days by the following scale [16]: 1 - no visible symptoms; 2 - from $1 \%$ to $25 \%$ of plants showing wilt symptoms; 3 - from $26 \%$ to $50 \%$ of plants displaying wilt symptoms; 4 - from $51 \%$ to $75 \%$ of plants showing wilt symptoms; 5 - greater than $75 \%$ of plants with wilt symptoms or dead.

\section{Results and discussion}

LAB antagonistic activity in vitro. Among 18 investigated $R$. solanacearum strains, $33 \%$ showed the susceptibility to enterococcal bacteriocin resulting in clear spots on bacterial lawns. MIC of bacteriocin varied from 1.00 to $0.02 \mathrm{mg} / \mathrm{ml}$.

To prove the suggestion that clear zones resulted from the action of proteinaceous bacteriocin, proteolysis with proteinase $\mathrm{K}$ was carried out athen the resulting mixture was spotted on Ralstonia lawn. No zone of inhibition or lysis occurred. The obtained results indicate that it was a proteinaceous substance, which caused the decline in bacterial population.

Producer strain (E. durans A5-11) could not cause itself the lysis zones around its colonies on $R$. solanacearum 7859 and 6189 strains. 
The effect of bacteriocin on target bacteria can differ in solid and liquid media [26]. To investigate this phenomenon in case of antagonistic substance, two strains were chosen showing differences in size lysis or inhibition zones on solid media ( $R$. solanacearum 6189 and $R$. solanacearum 7859).

In case of susceptible strain $R$. solanacearum 6189 , decline of cell quantity occurred from the first hour of experiment (Fig. 1).

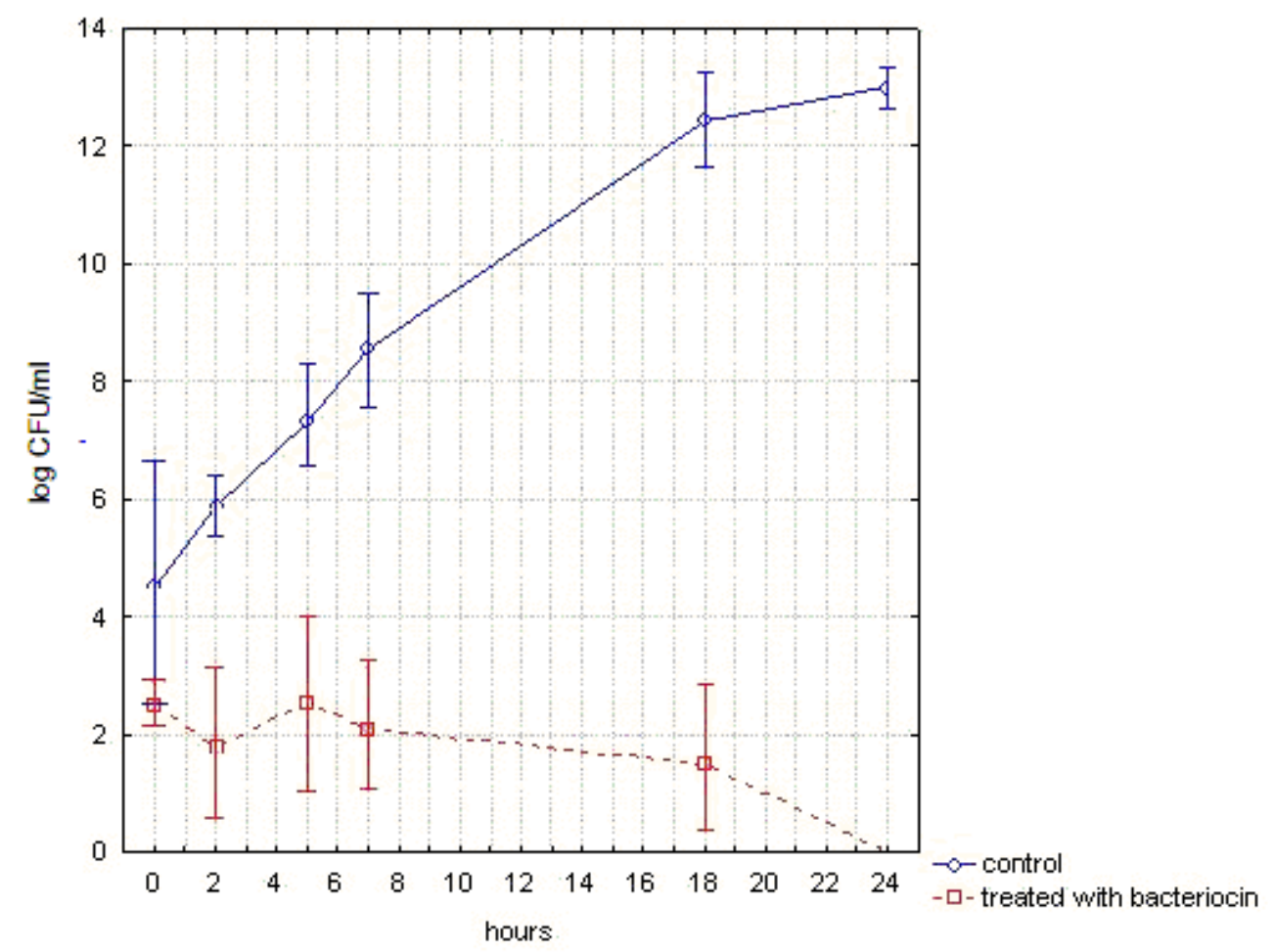

Fig. 1. Growth of $R$. solanacearum 6189 in LB broth in presence of E. durans A5-11 bacteriocin (concentration $0.03 \mathrm{mg} / \mathrm{ml}$ ). Error bars show standard deviation.

After 24 h of incubation no viable cells of Ralstonia were recovered from the suspension. Indeed, bacteriocins produced by enterococci are known for their lytic activities [21]. Additionally, the clearing of mixture of "target bacteria - bacteriocin" after first $2 \mathrm{~h}$ of incubation as was observed spectrophotometrically (Fig. 2), indicates that the effect of this antagonistic compound on Ralstonia is lytic and not inhibitory.

In case of less susceptible strain $R$. solanacearum 7859 , slight differences in viable cell quantities were observed during exponential phase (Fig. 3) due to decrease of its growth rate but at the end, after $24 \mathrm{~h}$ of cultivation, similar yields of cells in control and treated samples were obtained indicating the retarding effect of bacteriocin on the Ralstonia strain cell growth. 


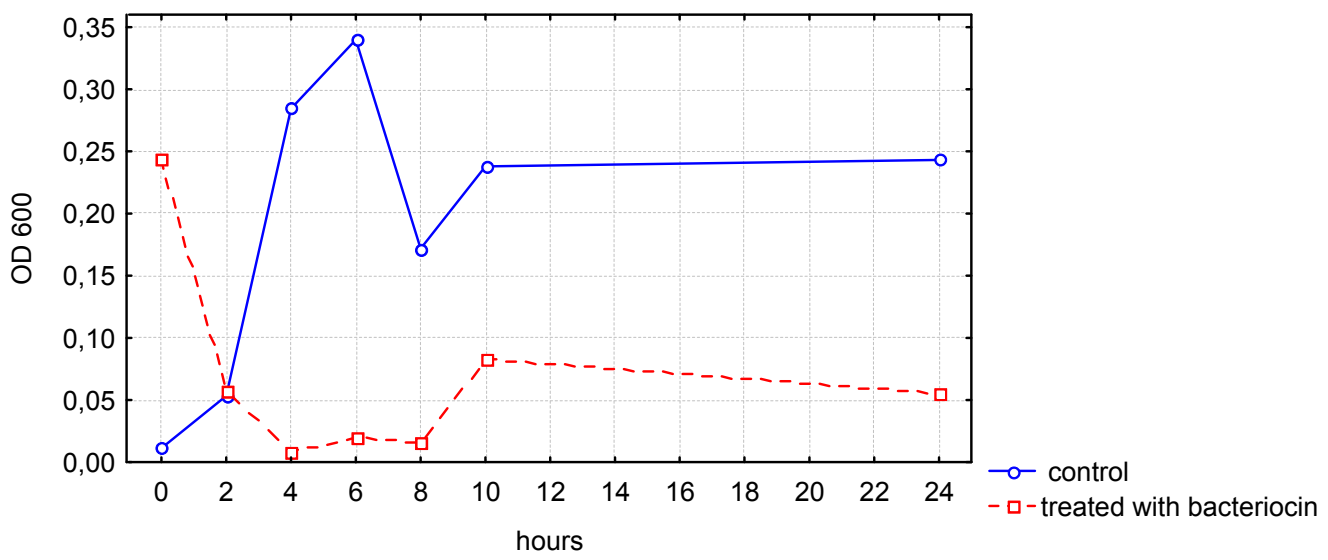

Fig. 2. Effect of E. durans A5-11 bacteriocin

(final concentration in a mixture $0.06 \mathrm{mg} / \mathrm{ml}$ ) on the growth of Ralstonia solanacearum 6189 in LB broth as measured spectrophotometrically.

This excludes the existence of lytic properties of studied bacteriocin A narrow, strain-restricted susceptibility of Gram-negative microorganisms to bacteriocins of LAB has been already described $[6 ; 15 ; 17]$. Susceptibility of $R$. solanacearum seems to be strain-specific too and it needs to be investigated with the vast diversity of target and producing strains.



Fig. 3. Growth of $R$. solanacearum 7859 in LB broth in presence of $E$. durans A5-11 bacteriocin (concentration $0.03 \mathrm{mg} / \mathrm{ml}$ ); bars show standard deviation.

The next step undertaken was to check antagonistic possibilities of LAB on test-plants. 


\section{Lactic acid bacteria antagonistic activity in vivo}

Dipping plant roots into suspensions with the pathogens and bacteriocin of $E$. durans A5-11 resulted in decreasing numbers of wilted tomatoes in case of the strain $R$. solanacearum 6189 (Fig. 4).



6189
6189 and $\mathrm{BCN}$

A

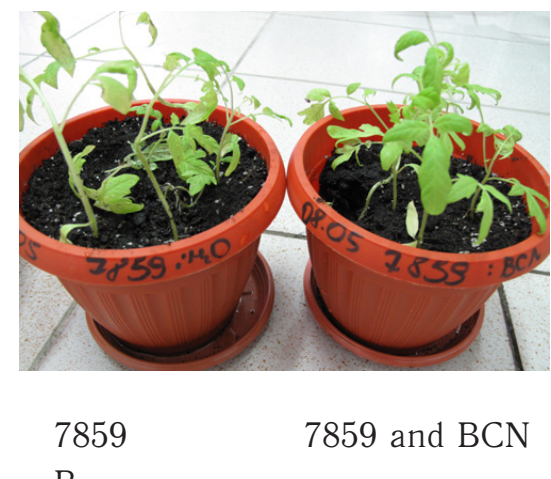

B

Fig. 4. Tomatoes treated with pathogen suspension and the mixture of pathogen and bacteriocin

A $-R$. solanacearum 6189 and enterococcal bacteriocin (BCN), $\mathrm{B}-$ R. solanacearum 7859 and BCN.

Thus, after 15 days of experiment, severity of wilt on 6189-inoculated plants was one unit lower as measured using Kelman and Person scale [16] (Table).

Table

Estimation of wilt symptoms on treated tomatoes

\begin{tabular}{|l|c|c|c|c|}
\hline $\begin{array}{c}\text { Assessment of } \\
\text { wilt symptoms }\end{array}$ & $\begin{array}{c}\text { Ralstonia } \\
\text { solanacearum } \\
\mathbf{6 1 8 9}\end{array}$ & $\begin{array}{c}\text { Ralstonia } \\
\text { solanacearum } \\
\mathbf{6 1 8 9} \\
\text { and E. durans } \\
\text { bacteriocin }\end{array}$ & $\begin{array}{c}\text { Ralstonia } \\
\text { solanacearum } \\
7859\end{array}$ & $\begin{array}{c}\text { Ralstonia } \\
\text { solanacearum } \\
7859 \\
\text { and E. durans } \\
\text { bacteriocin }\end{array}$ \\
\hline $\begin{array}{l}\text { Kelman and } \\
\text { Person scale }\end{array}$ & 4 & 3 & 4 & 4 \\
\hline $\begin{array}{l}\text { Number of dis- } \\
\text { eased plants (\%) }\end{array}$ & $63.6 \%$ & $45.0 \%$ & $72.7 \%$ & $75.0 \%$ \\
\hline
\end{tabular}

The inhibition of certain Ralstonia strains by LAB and by their secondary metabolites is a promising method of biological control meriting further study. However, several problems should be solved before. The laborious way of bacteriocin purification forces to search for the LAB strains releasing antagonistic compounds against Gram-negative bacteria during their growth on nutritional media.

This will eliminate the stage of bacteriocin extraction and purification from cell suspension. A lot of LAB strains originate from soil and plant surfaces $[29 ; 33]$ hence they should survive well on plant surfaces. 
Н.В. Ліманська, Т.В. Їваниця, І. Шуазе, Н.В. Коротаєва, Ж.Ю. Сергєєва, Ж.-М. Шобер, ....

Further investigations should be carried out including screening for even more effective antagonistic LAB and laboratory and field trials should confirm usefulness of their application on plants.

Acknowledgments. The work was supported by a program of Bilateral French-Ukrainian collaboration programme "Dnipro" (2011-2012) granted by the Ministry of Foreign and European Affairs of France and the State Agency of Science, Innovations, and Information of Ukraine, and in frames of the project "Science in universities" NU3-2011 granted by the Ministry of Education, Science, Sport and Youth of Ukraine.

\section{BIBLIOGRAPHY}

1. Batdorj B., Dalgalarrondo M., Choiset Y., Pedroche J., Mütro F., Prüvost H., Chobert J.-M., Haertlü T. Purification and characterization of two bacteriocins produced by lactic acid bacteria isolated from Mongolian airag // J Appl Microbiol. - 2006. - Vol. 101, № 4. - P. 837-848.

2. Bonjar G.H.Sh., Zamanian S., Aghighi S., Farrokhi P.R., Mahdavi M.J., Saadoun I. Antibacterial activity of Iranian Streptomyces coralus strain 63 against Ralstonia solanacearum // J. Biol. Sciences. - 2006. - Vol. 6, № 1. - P. 127-129.

3. Castro C.M., Motta S.D., Adiba F., Ribeiro R.L.D. Potential use of EM for control of phytopathogenic fungi and bacteria / Parr J.F., Hornick S.B., Simpsos M.E. (eds.). Proceedings of Third Int. Conf. on Kyusei Nature Farming. - 1995. - Washington: US Department of agriculture. P. 236-238.

4. Chakravarty G., Kalita M.Ch. Management of bacterial wilt of brinjal by P. fluorescens based bioformulation // ARPN J. Agricult. Biol. Science. - 2011. - Vol. 6, № 3. - P. 1-11.

5. Ciampi-Panno L., Fernandez C., Bustamante P., Andrade N., Ojeda $S$., Contreras A. Biological control of bacterial wilt of potatoes caused by Pseudomonas solanacearum // American Potato J. - 1989. - Vol. 66. P. $315-332$.

6. Ferreira A.E., Canal N., Morales D., Fuentefria D.B., Corcao G. Characterization of enterocins produced by Enterococcus mundtii isolated from human feces // Brazilian Archives of Biol. Technol. - 2007. -Vol. 50, № 2. - P. 249-258.

7. Gallardo P.B., Panno L.C. Biological control of bacterial wilt of potato induced by Pseudomonas solanacearum // Revista de Microbiologia. - 1989. - Vol. 20. - P. 18-26.

8. Hadji-Sfaxi I., Batdorj B., El-Ghaish S., Ahmadova A., Le Blay G., Barbier G. Haertlü T., Chobert J.M. Antimicrobial activity and safety of use of Enterococcus faecium PC4.1 isolated from Mongol yogurt // Food Control. - 2011. - Vol. 22. - P. 2020-2027.

9. Hartman G.L., Elphinstone J.G. Advances in the control of Pseudomonas solanacearum race 1 in major food crops / Bacterial wilt: the disease 
and its causative agent, Pseudomonas solanacearum. Hayward A.C., Hartman G.L. (eds.). - Wallington: CAB International, 1994. - P. 157-177.

10. Hayward A.C. Biology and epidemiology of bacterial wilt caused by Pseudomonas solanacearum // Annu. Rev. Phytopathol. - 1991. Vol. 29. - P. 65-87.

11. Hayward A. Systematics and phylogeny of Pseudomonas solanacearum and related bacteria. In Bacterial wilt: the disease and its causative agent, Pseudomonas solanacearum / Hartman G.L., Hayward A.C. (ed.)/ - Oxford: CAB International, 1994. - P. 127-135.

12. Higa T., Kinjo S. Effect of lactic acid fermentation bacteria on plant growth and soil humus formation // Proceedings of $1^{\text {th }}$ Int. Conf. on Kyusei Nature Farming. - 1989. - Khon Kaen, Thailand: Khon Kaen University. - P. 140-147.

13. Hu C.B., Zendo T., Nakayama J., Sonomoto K. Description of durancin TW-49M, a novel enterocin B-homologous bacteriocin in carrotisolated Enterococcus durans QU 49 // J. Appl. Microbiol. - 2008. Vol. 105. - P. 681-690.

14. Huang Q., Allen C. Polygalacturonases are required for rapid colonization and full virulence of Ralstonia solanacearum on tomato plants // Physiological and molecular plant pathology. - 2000. - Vol. 57. - P. 77 83.

15. Ignatova T., Iliev J., Kirilov N., Vassileva T., Dalgalarrondo M., Haertle T., Chobert J.-M., Ivanova I. Effect of oligosaccharides on the growth of Lactobacillus delbrueckii subsp. bulgaricus strains isolated from dairy products // J. Agricult. Food Chemistry. - 2009. - Vol. 57, № 20. P. 9496-9502.

16. Kelman A., Person L.H. Strains of Pseudomonas solanacearum differing in pathogenicity to tobacco and peanut // Phytopathology. 1961. - Vol. 51. - P. 158-162.

17. Line J.E., Svetoch E.A., Eruslanov B.V., Perelygin V.V., Mitsevich I.P., Levchuk V.P., Svetoch O.E., Seal B.S., Siragusa G.R., Stern N.J. Isolation and purification of enterocin E-760 with broad antimicrobial activity against gram-positive and gram-negative bacteria // Antimicrob. Agents Chemotherapy. - 2008. - Vol. 52, № 3. - P. 1094-1100.

18. Lwin M., Ranamukhaarachchi S.L. Development of biological control of Ralstonia solanacearum through antagonistic microbial populations // Int. J. Agricult. Biol. - 2006. - Vol. 8, № 5. - P. 657-660.

19. Messiha N.A.S., van Diepeningen A.D., Farag N.S., Abdallah S.A., Janse J.D., van Bruggen A.H.C. Stenotrophomonas maltophilia: a new potential biocontrol agent of Ralstonia solanacearum, causal agent of potato brown rot // Eur. J. Plant Pathol. - 2007. - Vol. 118. - P. 211-225.

20. Milling A., Meng F., Denny T.P., Allen C. Interactions with hosts at cool temperatures, not cold tolerance, explain the unique epidemiology of Ralstonia solanacearum race 3 biovar 2// Phytopathology. - 2009. Vol. 99. - P. 1127-1134. 
Н.В. Ліманська, Т.В. Їваниця, І. Шуазе, Н.В. Коротаєва, Ж.Ю. Сергєєва, Ж.-М. Шобер, ....

21. Nes I., Diep D.B., Holo H. Bacteriocin diversity in Streptococcus and Enterococcus // J. Bacteriol. - 2006. - Vol. 189, № 4. - P. 1189-1198.

22. Nguyen M.T., Ranamukhaarachchi S.L. Soil-borne antagonists for biological control of bacterial wilt disease caused by Ralstonia solanacearum in tomato and pepper // J. Plant Pathol. - 2010. - Vol. 92, № 2. - P. 395-406.

23. Nguyen M.Th., Ranamukhaarachchi S.L., Hannaway D.B. Efficacy of antagonist strains of Bacillus megaterium, Enterobacter cloacae, Pichia guilliermondii and Candida ethanolica against bacterial wilt disease of tomato // J. Phytology. - 2011. - Vol. 3, № 2. - P. 1-10.

24. Paret M.L., de Silva A.S., Criley R.A., Alvarez A.M. Ralstonia solanacearum race 4: risk assesment for edible ginger and floricultural ginger industries in Hawaii // Horttechnology. - Vol. 18, № 1. - P. 90-96.

25. Park K., Paul D., Kim Y.K., Nam K.W., Lee Y.K., Choi H.W., Lee S.Y. Induced systemic resistance by Bacillus vallismortis EXTN-1 suppressed bacterial wilt in tomato caused by Ralstonia solanaceaurum // Plant Pathol. - 2007. - Vol. 23. - P. 22-25.

26. Qi F., Chen P., Caufield P.W. The group I strain of Streptococcus mutans UA140, produces both the lantibiotic mutacin I and a nonlantibiotic bacteriocin, mutacin IV // Appl. Environm. Microbiol. - 2001. - Vol. 67. P. 15-21.

27. Tagg J.R., Dajani A.S., Wannamaker L.W. Bacteriocins of grampositive bacteria // Bacteriol. Rev. - 1976. - Vol. 40. - P. 722-756.

28. Thongwai N., Kunopakarn J. Growth inhibition of Ralstonia solanacearum PT1J by antagonistic bacteria isolated from soils in the northern part of Thailand // Chiang Mai J. Sci. - 2007. - Vol. 34, № 3. - P. 345-354.

29. Trias R., Baneras L., Montesinos E., Badosa E. Lactic acid bacteria from fresh fruit and vegetables as biocontrol agents of phytopathogenic bacteria and fungi // Int. Microbiol. - 2008. - Vol. 11. - P. 231-236.

30. Van Elsas J.D., Kastelein P., van Bekkum P. van der Wolf J.M., de Vries P.M., van Overbeek L.S. Survival of Ralstonia solanacearum biovar 2 , the causative agent of potato brown rot, in field and microcosm soils in temperate climates // Phytopathology. - 2000. - Vol. 90. - P. 1358-1366.

31. Wagih E. Neither indole acetic acid nor bacteriocin is apparently involved in the in vitro antagonism between the virulent and the avirulent strains of Pseudomonas solanacearum // J. Phytopathology. - 1991. Vol. 123. - P. 153-160.

32. Yabuuchi E., Kosako Y., Yano L., Hotta H., Nishiuchi Y. Validation of the publication of new names and new combinations previously effectively published outside the IJSB // Int. J. Syst. Bacteriol. - 1996. - Vol. 46. P. 625-626.

33. Yanagida F., Chen Y., Onda T., Shinohara T. Durancin L28-1A, a new bacteriocin from Enterococcus durans L28-1, isolated from soil // Letters in Appl. Microbiol. - 2005. - Vol. 40. - P. 430 - 435.

Стаття надійшла до редакції 08.06.2012 р. 
Н.В. Ліманська ${ }^{1}$, Т.В. Іваниця ${ }^{1}$, І. Шуазе ${ }^{2}$, Н.В. Коротаєва ${ }^{1}$, Ж.Ю. Сергєєва', Ж.-М. Шобер², В.О. Іваниця', Т. Ертле ${ }^{2}$

${ }^{1}$ Одеський національний університет імені I.I. Мечникова, вул. Дворянська, 2, Одеса, 65082, Україна

${ }^{2}$ Дослідницький відділ взаємодії та будови біополімерів 1268, Національний науководослідний інститут сільського господарства (INRA), ВР 71627, вул. де ля Жеродьєрі, 44316 Нант 3, Франція

\section{ВПЛИВ БАКТЕРIOЦИНУ ENTEROCOCCUS DURANS НА ЗБУДНИКА БАКТЕРІАЛЬНОГО ВІЛТУ}

\section{Реферат}

Досліджено вплив бактеріоцину Enterococcus durans A5-11 на ріст бактерій Ralstonia solanacearum та здатність їх викликати вілт у томатів. Нанесення бактеріоцину на газони штамів Ralstonia solanacearum показало, що $33 \%$ тестованих штамів фітопатогенів були чутливими до інгібуючої дії бактеріоцину. Мінімальні інгібуючі концентрації бактеріоцина та розміри зон лізису або інгібування росту бактерій варіювали залежно від штаму. Такі ж відмінності були виявлені щодо впливу бактеріоцину на бактерії штамів Ralstonia solanacearum у рідкому середовищі. Обробка коренів рослин томатів Lycopersicon esculentum Mill бактеріоцином $E$. durans A5-11 одночасно із зараженням бактеріями $R$. solanacearum 6189 призвела до зменшення кількості рослин томатів із симптомами вілту.

Ключові слова: бактеріоцин, Enterococcus durans, вілт томатів, Ralstonia solanacearum.

Н.В. Лиманская ${ }^{1}$, Т.В. Иваница ${ }^{1}$, И. Шуазе ${ }^{2}$, Н.В. Коротаева ${ }^{1}$, Ж.Ю. Сергеева ${ }^{1}$, Ж.-М. Шобер², В.А. Иваница ${ }^{1}$, Т. Эртле ${ }^{2}$

${ }^{1}$ Одесский национальный университет имени И.И. Мечникова, ул. Дворянская, 2, 65082, Одесса, Украина

${ }^{2}$ Исследовательский отдел взаимодействия и строения биополимеров 1268, Национальный научно-исследовательский институт сельского хозяйства (INRA), BP 71627 , ул. де ля Жеродьери, 44316 Нант 3, Франция

\section{ВЛИЯНИЕ БАКТЕРИОЦИНА ENTEROCOCCUS DURANS HА ВОЗБУДИТЕЛЯ БАКТЕРИАЛЬНОГО ВИЛТА}

\section{Реферат}

Исследовано влияние бактериоцина Enterococcus durans A5-11 на рост бактерий Ralstonia solanacearum и способность их вызывать вилт у томатов. Нанесение бактериоцина на газоны штаммов Ralstonia 
Н.В. Ліманська, Т.В. Їваниця, І. Шуазе, Н.В. Коротаєва, Ж.Ю. Сергєєва, Ж.-М. Шобер, ....

solanacearum показало, что 33\% тестированных штаммов фитопатогенов были чувствительными к ингибирующему действию бактериоцина. Минимальные ингибирующие концентрации бактериоцина и размеры зон лизиса или ингибирования роста бактерий варьировали в зависимости от штамма. Такие же различия были установлены для влияния бактериоцина на бактерии штаммов Ralstonia solanacearum в жидкой среде. Обработка корней растений бактериоцином $E$. durans A5-11 одновременно с заражением бактериями штамма $R$. solanacearum 6189 привела к уменьшению количества растений томатов с симптомами вилта.

Ключевые слов в: Enterococcus durans, бактериоцин, вилт томатов, Ralstonia solanacearum. 